\title{
Pengaruh Kepemimpinan Transformasional pada Masa Pandemi Covid 19 Terhadap Kinerja Karyawan Melalui Culture Control dan Komitmen Organisasi
}

\author{
Sabaruddinsah \\ Universitas Sultan Ageng Tirtayasa \\ Sabaruddin77@gmail.com \\ Neng Asiah \\ Universitas Pelita Bangsa \\ neng.asiah@pelitabangsa.ac.id
}

\begin{abstract}
This study aims to examine the effect of transformational leadership on employee performance with control culture and organizational commitment as intervening variables.T his research is a type of quantitative research, data is collected using primary data and questionnaires to obtain information from respondents, namely middle managers who work in manufacturing companies in Bekasi City and Regency. The analytical method used is Structural Equation Modeling (SEM) with Partial Least Square (PLS) Path Modeling with SmartPLS 3.0 analysis tool.Based on the results of the study that transformational leadership affects control culture, organizational commitment and employee performance, control culture and organizational commitment affect employee performance, transformational leadership affects employee performance through control culture and organizational commitment.
\end{abstract}

Keywords Transformational leadership, control culture, organizational commitment and employee performance

\section{PENDAHULUAN}

Setiap perusahaan mempunyai strategi untuk menghadapi masa pandemi Covid-19 seperti sekarang ini yang merupakan bagian fenomena yang mutlak dan tidak dapat dihindari. Perusahaan harus menyiapkan strategi yang mampu mempertahankan bisnisnya untuk melewati masa krisis yang di sebabkan oleh pandemi dan melakukan transformasi dan inovasi untuk menghadapi persaingan bisnis yang kompleks seperti sekarang ini.

Kemampuan sumber daya manusia harus benar-benar teruji sehingga mampu mengerjakan semua pekerjaan yang dibebankan kepadanya secara benar dan menghasilkan hasil yang sempurna, baik kuantitas maupun kualitasnya (Kasmir, 2016). Organisasi pada umumnya percaya bahwa untuk mencapai keunggulan harus mengusahakan kinerja individual yang setinggi tingginya, karena pada dasarnya kinerja individual memengaruhi kinerja tim atau kelompok kerja dan pada akhirnya memengaruhi kinerja organisasi secara keseluruhan (Zeit, 1994).

Kinerja seseorang menunjukkan tingkat kompetensi atau profesionalismenya dan kemampuan kinerja karyawan merupakan topik yang multidimensional dan sangat penting 
untuk kesuksesan organisasi (Chaplin, 2005). Selain itu, Kinerja yang baik haruslah di dukung dari beberapa aspek lain untuk menyesuaikan diri dengan perkembangan lingkungan, dan dalam upaya untuk mempertahankan kelangsungan hidup bisnisnya (Sunyoto dan Burhanudin, 2015), akan tetapi sebagian besar faktor tersebut dipengaruhi oleh pemimpin, baik sifat yang melekat pada pemimpin maupun gaya kepemimpinan yang digunakan dalam mengelola organisasi tersebut (Sunyoto danBurhanudin, 2015).

Banyak teori kepemimpinan yang dikemukakan guna mengkatalisasi proses dan mengkanalisasi sumber daya manusia. Setidaknya, teori kepemimpinan transformasional merupakan satu dari banyak teori kepemimpinan yang dipercaya mampu membawa angin segar perubahan organisasi karena kemampuan seseorang pemimpin dalam mempengaruhi pengikutnya merupakan faktor dominan yang menentukan keberhasilan suatu organisasi, karena pemimpin memiliki peran sebagai koordinator, motivator, dan katalisator yang akan membawa organisasi pada puncak keberhasilan (Sunyoto dan Burhanudin, 2015).

Menurut Mowday, et al (1992) salah satu faktor yang mempengaruhi komitmen terhadap organisasi adalah karakteristik struktural yang meliputi karakteristik organisasi beserta seluruh kebijakan yang berlaku termasuk di dalamnya kebijakan pimpinan organisasi. Management control system (MSC) merupakan hal yang utama dalam menghadapi lingkungan bisnis yang semakin kompetitif. MCS merupakan alat yang didesain untuk membantu proses pengambilan keputusan dengan menggunakan formal control dan informal control guna mencapai tujuan organisasi. MCS merupakan proses seorang manajer memastikan sumber daya yang dimiliki digunakan secara efektif dan efisien. Sehingga MCS dapat digunakan sebagai sarana monitoring bagi organisasi agar tujuan organisasi sesuai ekspektasi manajemen. Formal dan informal control berpengaruh terhadap kinerja organisasi. MCS juga berpengaruh pada inovasi produk karena meningkatkan pada kreatifitas organisasi (Galih, 2017). Salah satu bentuk dari MCS adalah Culture Control (CC).

Culture Control adalah sekelompok nilai tertulis maupun tidak tertulis yang menjadi aturan-aturan sebagai landasan pembentuk budaya organisasi dan prilaku pegawai (Ismail, 2016). Culture Control sebagai suatu sistem pengendalian yang dibuat untuk menciptakan lingkungan sosial yang mendorong prilaku individu bertindak dan berprilaku sesuai dengan nilai dan norma yang berlaku dalam organisasi (Merchant \& Stede, 2007). Oentoro (2014) menyatakan culture control memiliki manfaat dimana organisasi tidak perlu membuat kebijakan, manual, prosedur yang detail mengenai prilaku karyawan dalam bertindak, sebab culture control telah memberikan arahan dan batasan prilaku sesuai nilai dan norma dalam organisasi. Culture Control merupakan bentuk sistem pengendalian yang memiliki biaya yang rendah. Hal ini karena tidak memerlukan sistem yang canggih. dan bergerak berdasarkan acuan budaya organisasi pada sebuah perusahaan, culture control dapat diterapakan di berbagai jenis organisasi termasuk perusahaan dan memiliki resiko efek samping yang tidak membahayakan (Galih, 2017).

Penelitian sebelumnya yang dilakukan oleh Oentoro (2014) mengenai kemampuan Culture Control dalam meningkatkan kapabilitas dan kinerja organisasi merupakan salah satu bentuk keunggulan Culture Control. Walaupun demikian, Culture Control juga memiliki beberapa kelemahan. Salah satu kelemahan Culture Control ialah konsep dan penerapan Culture Control masih ambigu. Hal ini disebabkan masih tumpang-tindihnya konsep Culture Control dengan bentuk control lainya (Ismail, 2016). Oleh sebab itu diperlukan penelitian yang lebih jauh dan komprehensive untuk mengetahui bagaimana konsep dan penerapan Culture Control. Culture Control dapat diterapkan di berbagai jenis organisasi baik organisasi publik maupun privat selama organisasi tersebut memiliki budaya organisasi yang kuat. 
Kepemimpinan transformasional yang berjalan dengan baik dan kualitas karyawan merupakan suatu indikasi adanya komitmen dalam diri seorang pemimpin dan juga karyawan di perusahaan tempatnya berkerja yang akan membuat mereka bekerja secara sungguhsungguh untuk mewujudkan tujuan organisasi yang akan di capai dengan sepenuh hati demi kemajuan organisasinya. Komitmen organisasional dianggap sebagai masalah organisasi krusial yang dihadapi oleh manajer (Lo et al., 2010) Komitmen organisasi adalah sejauh mana seorang karyawan bersedia mengerahkan energinya dan merasa bangga berada bersama organisasi (Mowday dkk., 1979). Tiga bentuk komitmen organisasi dijelaskan oleh literatur yaitu komitmen organisasi, komitmen normatif dan komitmen kontinuan (Thomsen et al., 2016). Mengikuti Mowday et al (1979) konseptualisasi dari komitmen organisasi dalam penelitian ini mengambil bagian dari komitmen organisasi sebagaimana terdiri dari karyawan yang memiliki keterikatan pribadi, keterlibatan, dan identifikasi dengan organisasi yang mempekerjakannya. Komitmen organisasi telah dikaitkan dengan perilaku karyawan yang menguntungkan, seperti kecil kemungkinannya untuk berhenti dari pekerjaan mereka dan memberikan upaya ekstra ke dalam pekerjaan mereka (Powell dan Meyer, 2004). Oleh karena itu, dalam penelitian ini dapat dikatakan bahwa karyawan yang mempunyai komitmen organisasi akan lebih bernilai bagi perusahaan dibandingkan kedua tipe komitmen yang lain karena sudah melibatkan faktor emosional sehingga karyawan dengan komitmen organisasi karyawan akan bertugas dengan perasaan senang dan menikmati perannya.

Penelitian ini bersifat pengembangan dari para peneliti sebelumnya, sehingga dibutuhkan hasil uji hipotesis harus didukung oleh penelitian- penelitian sebelumnya. Hal ini di dasarkan pada penelitian sebelumnya yang dilakukan oleh Owais Nazir (2017) di India, tingkat keterlibatan dan komitmen terhadap organisasi sangat bergantung pada dukungan organisasi yang dirasakan. Garg dan Dhar (2014) dalam penelitian menyatakan komitmen organisasi pada karyawan merupakan bentuk konsekuensi dari keterlibatan gaya kepemimpinan pada suatu organisasi dan juga terdapat penelitian yang menyatakan tentang gaya kepemimpinan berpengaruh positif terhadap kinerja pegawai, gaya kepemimpinan berpengaruh positif terhadap cultur control, cultur control berpengaruh positif terhadap kinerja karyawan (Galih, 2017).

\section{LANDASAN TEORI Kinerja karyawan}

Kinerja karyawan dapat diartikan sebagai sejauh mana seseorang melaksanakan tanggung jawab dan tugas kerjanya (Singh et al (2012). Searah dengan pendapat tersebut, Maulizar (2012) menyimpulkan kinerja karyawan adalah hasil kerja yang dicapai oleh karyawan dalam suatu organisasi sesuai dengan wewenang dan tanggung jawab yang diberikan organisasi dalam upaya mencapai visi, misi, dan tujuan organisasi bersangkutan secara legal, tidak melanggar hukum dan sesuai dengan moral maupun etika. Menurut Rivai dan Sagala (2011), kinerja merupakan perilaku nyata yang ditampilkan oleh setiap orang sebagai prestasi kerja yang dihasilkan oleh karyawan sesuai dengan perannya dalam perusahaan. Kinerja karyawan merupakan hal yang sangat penting bagi perusahaan dalam upaya mencapai tujuannya

\section{Kepemimpinan Transformasional}

Gaya kepemimpinan trasformasional merupakan pemimpin yang menginspirasi para 
pengikutnya untuk mengenyampingkan kepentingan pribadi mereka dan memiliki kemampuan mempengaruhi yang luar biasa (Robbins dan Judge, 2008:90). Pemimpian trasformasional mampu menyatukan seluruh bawahannya dan mampu mengubah keyakinan, sikap dan tujuan pribadi masing-masing bawahan demi mencapai tujuan yang ditetapkan (Humphyers, 2002; lie et al., 2003; Rafferti \& Griffin, 2004; Yammarino et al., 1993). Nugroho (2006) menjelaskan kemampuan pemimpin transformasional mengubah sistem nilai bawahan demi mencapai tujuan diperoleh dengan mengembangkan salah satu atau seluruh faktor yang merupakan dimensi kepemimpinan transformasional, yaitu: karisma (kemudian diubah menjadi pengaruh ideal atau idealized influence), inspirasi (inspirational motivation), pengembangan intelektual (intellectual stimulation), dan perhatian pribadi (individualized consideration).Idealized influence merupakan dimensi terpenting kepemimpinan transformasional karena memberikan inspirasi dan membangkitkan motivasi bawahan (secara emosional) untuk menyingkirkan kepentingan pribadi demi pencapaian tujuan bersama (Humphreys, 2002; Rafferty \&Griffin, 2004)

\section{Culture Control}

Menurut Merchant dan Van der Stede (2007) menyatakan bahwa cultural control merupakan bentuk pengendalian yang dirancang untuk mendorong pengawasan sesama karyawan, merupakan tekanan sosial yang dipakai oleh badan usaha terhadap individu yang menyimpang dari norma dan nilai-nilai yang berlaku pada badan usaha tersebut. Cultural control didesain untuk mendorong terciptanya mutual-monitoring, yaitu sebuah tekanan bagi individu (seorang karyawan) untuk mematuhi norma-norma dan nilai-nilai yang ada di dalam sebuah kelompok di mana ia berada. Budaya merupakan seperangkat atau keseluruhan pola pikir, perasaan, tindakan dan karakteristik kelompok tertentu dari berbagai perspektif, mulai dari bahasa, agama, kebiasaan sosial dan kesenian yang membedakan dengan kelompok lain (Hofstede et al., 1990; Jyoti dan Kour, 2015). Budaya dibangun atas tradisi, norma, kepercayaan, nilai, ideologi, dan cara bersikap. Budaya organisasi relatif tetap dari waktu ke waktu, bahkan ketika terjadi perubahan kondisi bisnis. Budaya organisasi yang kuat dan fungsional mendorong karyawan untuk bekerjasama satu dengan lain secara bersinergis. Namun, hal ini juga menunjukan bahwa meski pengarahan dan kekompakkan memberi manfaat tertentu, budaya yang kuat terkadang dapat menjadi sumber terjadinya inersi yang dapat menghalangi perubahan dan adaptasi terhadap perubahan kondisi bisnis.

\section{Komitmen Organisasi}

Darmawan (2013) menyatakan bahwa Komitmen organisasi adalah suatu konstruk psikologis yang merupakan karakteristik hubungan anggota organisasi dengan organisasinya, dan memiliki implikasi terhadap keputusan individu untuk melanjutkan keanggotaannya dalam berorganisasi. Sopiah (2017) mendefinisikan komitmen organisasional sebagai suatu sikap yagng merefleksikan perasaan suka atau tidak suka dari karyawan terhadap organisasi. Komitmen karyawan pada organisasi sebagai ikatan kejiwaan individu terhadap organisasi yang mencakup keterlibatan kerja, kesetiaan, dan perasaan percaya terhadap nilai - nilai organisasi.

\section{Pengembangan Hipotesis}

\section{Hubungan Kepemimpinan Transfomasional terhadap Kinerja Karyawan}

Setiap organisasi menginginkan dan membutuhkan anggota organisasi yang bersedia melakukan tugas yang tidak tercantum dalam deskripsi pekerjaannya, fakta menunjukkan 
organisasi yang memiliki anggota organisasi seperti itu memiliki kinerja yang lebih baik daripada organisasi lain (Robbins dan Judge, 2008:40). perspektif gaya kepemimpinan transformasional yang menjelaskan bagaimana pemimpin mengubah tim atau organisasi dengan men- ciptakan, mengkomunikasikan dan membuat model visi untuk organisasi atau unit kerja dan memberi inspirasi pekerja untuk berusaha mencapai visi tersebut. (Yulk, 2010), jika pemimpin berhasil memengaruhi bawahan dengan visinya, menanamkan karismanya, memotivasi dan menjadi inspirator, menstimulasi intelektual, kreatifitas dan menghargai karyawannya maka dapat dipastikan karyawan akan bekerja dengan baik, sungguh-sungguh dan loyal pada perusahaan sehingga kinerjanya meningkat (Robbins, 2010). Pernyataan ini dipertegas dengan penelitian yang dilakukan oleh Modiani (2012) yang menemukan bahwa kepemimpinan transformasional berpengaruh positif terhadap kinerja karyawan. Berdasarkan uraian penelitian tersebut, maka dikemukakan hipotesis sebagai berikut:

\section{H1: Kepemimpinan Transformasional memiliki pengaruh signifikan dan positif terhadap Kinerja Karyawan.}

\section{Hubungan Kepemimpinan Transformasional terhadap Kultur Kontrol}

Teori kepemimpinan transformasional dimulai dengan konsep oleh Burns (1978) dan Bass (1985) . Menurut Bass, pemimpin transformasional merangsang bawahannya untuk membuat persepsi tentang kepemimpinan dengan cara pandang baru karena ada rangsangan intelektual. Pemimpin mampu menjadikan persepsi sebagai individu yang dapat mendukung dan memberikan perhatian kepada bawahan dengan pertimbangan individual, melalui motivasi dan karisma yang inspiratif ( Bass, 1985 ). Pemimpin dalam mencapai tujuan organisasi memerlukan strategi dengan menciptkan budaya organisasi untuk mendukungnya. Culture Control merupakan bagian dari MCS dan berfungsi mengontrol sifat dan prilaku karyawan dalam berorganisasi (Ismail, 2015). Dengan demikian MCS merupakan alat untuk mengendalikan organisasi dan mengarahkan perilaku karyawan sesuai keinginan pihak manajemen guna mencapai tujuan organisasi (Anthony Robert \& Vijay, 2007). Berdasarkan uraian penelitian tersebut, maka dikemukakan hipotesis sebagai berikut:

\section{H2 : Kepemimpinan transformasional berpengaruh signifikan dan positif terhadap kultur kontrol.}

\section{Hubungan Kepemimpinan Transformasional terhadap Komitmen organisasi}

Pimpinan bergaya transformasional dapat mengoptimalkan perkembangan individu dan memahami kebutuhannya sehingga karyawan lebih terdorong untuk berkontribusi lebih bagi organisasi (Dhawan \& Mulla, 2011). Penelitian yang mempelajari hubungan antara kepemimpinan transformasional dan komitmen organisasi sudah banyak dilakukan antaralain Giovanita (2017) meneliti karyawan di sektor keuangan dan Suseno \& Sugiyanto (2010) dengan responden karyawan pabrik gula menyatakan bahwa kepemimpinan transformasional mempunyai pengaruh signifikan terhadap komitmen organisasi. Logika dari hipotesis yang akan digunakan dalam penelitian ini adalah semakin tinggi komitmen organisasi yang dimiliki oleh karyawan di pengaruhi oleh gaya kepemimpinan atasannya. Hal ini di dukung oleh penelitian yang dilakukan oleh Dlamini et al (2017) menggunakan responden karyawan rumah sakit mengatakan bahwa ada korelasi positif dan signifikan antara kepemimpinan transformasional dan komitmen organisasi. Selanjutnya studi dari Ramachandran dan Khrisnan (2009) pada 98 karyawan di US, India, dan China juga mengungkapkan hal serupa. Berdasarkan uraian penelitian tersebut, maka dikemukakan hipotesis sebagai berikut:

\section{H3 : Kepemimpinan Transformasional memiliki hubungan signifikan dan positif}




\section{dengan Komitmen organisasi.}

\section{Hubungan culture control terhadap Kinerja Karyawan}

Culture Control didesign untuk mendukung mutual monitoring yakni sebuah bentuk tekanan grup yang amat kuat kepada individu agar tidak keluar dari nilai dan norma organisasinya berada. Cultural Control akan sanggat efektif apabila ketika anggota organisasi saling memiliki ikatan emosional antar satu sama lain. Culture Control ialah untuk memberikan informasi yang bermanfaat dalam pengambilan keputusan, perencanaan dan evaluasi maka dari ini berpengaruh dalam kinerja (Shindie et al, 2015). Culture Control merupakan bagian dari MCS dan berfungsi mengontrol sifat dan prilaku karyawan dalam berorganisasi (Ismail, 2015; Jaworski et al., 1993; Merchant \& Stede, 2007). Culture Control merupakan nilai-nilai dan keyakinan yang digunakan sebagai norma untuk mengatur prilaku dalam organisasi. (Jaworski et al., 1993) mengungkapkan penggunaan control system berpengaruh dalam meningkatkan kinerja organisasi. Selain itu penelitian yang dilakukan oleh (Kallunki, Laitinen, \& Silvola, 2011) menemukan bahwa guna mencapai kinerja organisasi yang terbaik dibutuhkan formal dan informal control system. Dengan demikian sebagai bagian dari MCS Culture Control berpengaruh terhadap kinerja organisasi dengan cara memberikan informasi yang berguna dalam pencapaian tujuan organisasi. Hal ini di dukung dengan adanya hasil penelitian oleh Galih (2017) yang menyatakan Cultur control berpengaruh positif terhadap kinerja karyawan. Berdasarkan uraian penelitian tersebut, maka dikemukakan hipotesis sebagai berikut:

\section{H4 : Kultur Kontrol memiliki pengaruh signifikan dan positif terhadap kinerja karyawan.}

\section{Hubungan Komitmen organisasi terhadap Kinerja Karyawan}

Karyawan dengan komitmen organisasi tinggi akan menunjukkan kinerja yang lebih baik daripada karyawan dengan komitmen organisasi rendah karena mereka memiliki keterikatan emosional sehingga memunculkan rasa memiliki pada organisasi dan senantiasa akan berupaya lebih baik untuk kemajuan organisasi (Fitri astuti et al., 2016). Seorang karyawan yang memiliki komitmen organisasi dalam dirinya akan menunjukkan rasa senangnya berada di organisasi sehingga muncul rasa memiliki karena menjadi bagian dari organisasi. Semakin tinggi komitmen organisasi dalam arti memiliki rasa senang sebagai bagian dari organisasi dan merasa bertanggung jawab untuk kemajuan organisasi tinggi maka karyawan akan menunjukkan hal positif bagi organisasi sehingga berdampak pada meningkatnya kinerja karyawan. Hal ini sesuai dengan penelitian Negin et al. (2013) membuktikan adanya pengaruh positif dan signifikan komitmen organisasi pada kinerja karyawan. Berdasarkan uraian penelitian tersebut, maka dikemukakan hipotesis sebagai berikut:

\section{H5 : Komitmen organisasi berpengaruh positif dan signifikan pada kinerja karyawan.}

\section{Hubungan Kepemimpinan transformasional terhadap Kinerja Karyawan melalui culture control}

Teori kontingensi adalah teori kesesuaian pemimpin yang berarti menyesuaikan pemimpin dengan kondisi yang tepat Fiedler's (1964). Pemimpin dengan gaya transformasional mengubah kesadaran para pengikut akan persoalan-persoalan dengan membantu mereka memandang masalah lama dengan cara-cara baru, dan mereka mampu menggairahkan, membangkitkan, dan mengilhami para pengikut untuk mengeluarkan upaya ekstra demi mencapai sasaran kelompok sehingga dapat menciptakan kinerja karyawan yang baik (Robbins, 2007). MCS merupakan proses seorang manajer memastikan sumber daya 
yang dimiliki digunakan secara efektif dan efisien. Sehingga (MCS) dapat digunakan sebagai sarana monitoring bagi organisasi agar tujuan organisasi sesuai ekspektasi manajemen (Merchant \& Stede, 2007) hipotesis ini untuk menguji bagimana meningkatkan kinerja karyawan dengan mempertimbangkan seorang pemimpin perusahaan untuk menerapkan gaya kepemimpinan transformasional yang mana dalam pemimpin diperlukan perhatian kepada bahawannya yang nantinya akan membuat budaya organisasi yang mendukung tujuan organisasi dengan kultur kontrol untuk mengetahui apakah karyawan siap menghadap perubahan dalam lingkungan organisasi karena hal ini dapat mempengaruh kesuksesan tujuan organisasi. Berdasarkan uraian penelitian tersebut, maka dikemukakan hipotesis sebagai berikut:

\section{H6 : Kepemimpinan transformasional memiliki pengaruh terhadap kinerja karyawan melalui kultur kontrol}

\section{Hubungan Kepemimpinan Transformasional terhadap Kinerja Karyawan melalui Komitmen organisasi sebagai mediator}

Teori Kontijensi (Fieldler, 1978) di bidang teori organisasi telah memberikan kontribusi terhadap pengembangan akuntansi manajemen, terutama dalam menjelaskan faktor-faktor yang mempengaruhi prestasi organisasi. Kepemimpinan transformasional membuat bawahan merasakan kepercayaan, kebanggaan, loyalitas dan rasa hormat terhadap atasan dan termotivasi untuk melakukan lebih dari apa yang diharapkan. Pengaruh yang diberikan dalam kepemimpinan transformasional berpengaruh pada loyalitas karyawan dan tingkat komitmen karyawan terhadap organisasi (Emery dan Barner, 2007). Robbins pada tahun 2006 mengatakan bahwa tingkat keefektifan kepemimpinan dapat mendorong dan mengembangkan komitmen organisasi pada individu (Koesmono, 2007). Penerapan kepemimpinan yang baik dan efektif membuat tingkat loyalitas karyawan meningkat dan berdampak positif terhadap komitmen organisasi karyawan. Yousef (2000), menyatakan bahwa komitmen organisasi menghubungkan antara perilaku kepemimpinan dengan kinerja. Karyawan yang berkomitmen dengan pekerjaannya akan memiliki kinerja yang tinggi (Trisnaningsih, 2007). Hal ini didukung oleh hasil penelitian Sahidillah Nurdin \& Acep Rohendi (2016) yang menyatakan bahwa kepemimpinan transformasional berpengaruh signifikan terhadap kinerja karyawan melalui komitmen organisasi. Berdasarkan uraian penelitian tersebut, maka dikemukakan hipotesis sebagai berikut:

\section{H7 : Kepemimpinan Transformasional memiliki pengaruh terhadap Kinerja Karyawan melalui Komitmen organisasi}

\section{METODOLOGI PENELITIAN}

Penelitian ini merupakan jenis penelitian kuantitatif dengan melakukan uji hipotesis. Penelitian kuantitatif yaitu sebuah metode penelitian yang bertujuan menggambarkan fenomena atau gejala sosial secara kuantitatif atau menganalisa bagaimana fenomena atau gejala sosial yang terjadi di masyarakat saling berhubungan satu sama lain (Sudaryono, 2017). Dengan metode kuantitatif akan diperoleh signifikansi hubungan antar variabel yang diteliti. Menurut Sekaran (2016) populasi mengacu pada keseluruhan kelompok orang, kejadian, atau hal minat yang ingin diketahui oleh peneliti. Populasi yang digunakan pada penelitian ini adalah Perusahaan Manufaktur yang berada di Kota dan Kabupaten Bekasi. Alasan peneliti perusahaan manufaktur dalam penelitian ini adalah karena perusahaan manufaktur merupakan industri yang cukup unik dan memiliki kapasitas pekerjaan yang rumit dari mulai proses 
produksi sampai barang jadi yang siap dijual. Hal ini menyebabkan kecenderungan perusahaan membutuhkan cara yang efektif untuk meningkatkan kinerja karyawannya. Adapun pemilihan perusahaan manufaktur yang berada di Jawa Barat karena di lokasi ini terdapat banyak industri besar maupun kecil dan juga banyak perusahaan yang mempunyai kemampuan untuk bertahan ditengah pandemi Covid-19. Sampel adalah bagian dari jumlah karakteristik yang dimiliki oleh populasi (Sugiyono, 2017). Metode penentuan sampel yang digunakan adalah didasarkan pada metode non probability sampling yaitu teknik pengambilan sampel yang tidak memberikan peluang atau kesempatan yang sama bagi setiap unsur atau anggota populasi untuk dipilih menjadi sampel, metode inidigunakan karena tujuan penelitian hanya mendeskripsikan sebuah objek penelitian tanpa melakukan generalisasi terhadap populasi, dengan menggunakan tektik pendekatan purposive sampling. Kriteria pemilihan sampel perusahaan manufaktur dalam penelitian ini yang diajukan sebagai berikut:

- Perusahaan manufaktur berskala besar berdasarkan Peraturan Menteri Perdagangan Republik No: 46/M-DAG/PER/9/2009 tentang Surat Izin Usaha Perdagangan.

- Perusahaan yang di kategorikan besar berdasarkan BPS (Badan Pusat Statistik) Jawa Barat perusahaan industri yang dikatakan sedang, bila perusahaan industri dikategorikan besar apabila mempunyai karyawan lebih dari seratus.

- Middle manajer yang bertanggung jawab dalam perencanaan, pengawasan dan pembuat keputusan, yaitu: manajer HRD, manajer pemasaran, manajer operasional, manajer keuangan, dan manajer produksi.

- Middle manajer yang bekerja dengan masa kerja minimal 2 tahun bekerja sebagai manajer di perusahaan tersebut.

- Bersedia manjadi responden.

Penelitian ini merupakan analisis dari data primer yaitu data yang diperoleh dari tangan pertama untuk analisis berikutnya untuk menemukan solusi atau masalah yang diteliti (Sekaran, 2011). Penelitian ini menggunakan kuesioner sebagai alat bantu. Data primer yang dihasilkan dalam penelitian ini merupakan hasil dari tanggapan responden terhadap variabel-variabel penelitian yang akan diuji. Operasional variabel adalah unsur penelitian yang memberitahukan bagaimana caranya mengukur suatu variabel, dengan kata lain semacam petunjuk pelaksanaan bagaimana caranya mengukur suatu variable (Sugiyono, 2017). Variabel yang digunakan dalam penelitian ini adalah variabel Kepemimpinan Transformasional, sebagai variabel independen, variabel Kinerja Karyawan sebagai variabel dependen dan Kultur Kontrol dan Komitmen organisasi sebagai variabel interveing. Dalam penelitian ini skala yang digunakan adalah skala Likert. Responden hanya memberikan persetujuan atau ketidaksetujuannya terhadap butir soal tersebut, skala ini dimaksudkan untuk mengukur setiap individu dalam dimensi yang sama dan individu menempatkan dirinya ke arah satu kontinuitas dari butir soal. Skala Likert mempunyai gradiasi dari sangat positif sampai sangat negative dengan menggunakan skala ordinal 1 sampai 5. Analisis statistik pada penelitian ini menggunakan software Partial Least Square (PLS) versi 3

\section{HASIL DAN PEMBAHASAN Pengujian Hipotesis Menurut Inner Model}

Pengujian inner model atau model struktural dilakukan untuk melihat hubungan antara konstruk, nilai signifikansi dan $R$-Square dari model penelitian. Model struktural dievaluasi dengan menggunakan $R$-Square untuk konstruk dependen (Ghozali, 2012). Batas untuk menolak dan menerima hipotesis yang diajukan yaitu lebih dari 1,96 nilai t statistiknya, dimana 
apabila $\mathrm{t}$ statistik lebih besar dari $\mathrm{t}$ tabel $(1,96)$ maka hipotesis diterima, sebaliknya jika nilai $\mathrm{t}$ statistik lebih kecil dari t tabel $(1,96)$ maka hipotesis ditolak. Adapun inner model (Path Coefficients) dalam penelitian ini terdapat dalam tabel 1 sebagai berikut:

Tabel 1. Path coefficients

\begin{tabular}{cllccc}
\hline & $\begin{array}{l}\text { Original } \\
\text { Sample }\end{array}$ & $\begin{array}{l}\text { Sample } \\
\text { Mean }\end{array}$ & $\begin{array}{c}\text { Standard } \\
\text { Deviation }\end{array}$ & T Statistics & Keterangan \\
\hline CC -> KK & 0,278 & 0,274 & 0,057 & 4,861 & Diterima \\
\hline KA -> KK & 0,454 & 0,454 & 0,07 & 6,476 & Diterima \\
\hline KT -> CC & 0,789 & 0,791 & 0,033 & 23,699 & Diterima \\
\hline KT -> KA & 0,806 & 0,808 & 0,03 & 26,864 & Diterima \\
\hline KT - > KK & 0,870 & 0,872 & 0,021 & 39,728 & Diterima \\
\hline KT -> KA -> KK & 0,336 & 0,362 & 0,078 & 4.709 & Diterima \\
\hline KT -> CC -> KK & 0,220 & 0,222 & 0,055 & 3.978 & Diterima \\
\hline
\end{tabular}

\section{Sumber: Output SmartPLS (2021)}

Hasil pengolahan data pada dengan menggunakan SmartPLS dapat dilihat pada tabel 4.14 diketahui bahwa hubungan kultur kontrol dan kinerja karyawan mempunyai hubungan yang signifikan karena nilai t-statistik 4,861 diatas nilai t-tabel 1,96 dan mempunyai korelasi positif karena nilai original sampel diatas 0 yaitu 0,278. Hubungan antara omitmen afektif dengan kinerja karyawan mempunyai hubungan yang signifikan karena nilai t-statistik 6,476 diatas nilai t-tabel 1,96 dan mempunyai korelasi positif karena nilai original sampel diatas 0 yaitu 0,454. Hubungan antara kepemimpinan transformasional dengan kultur kontrol mempunyai hubungan yang signifikan karena nilai t-statistik 23,699 diatas nilai t-tabel 1,96 dan mempunyai korelasi positif karena nilai original sampel diatas 0 yaitu 0,789 .

Hubungan antara kepemimpinan transformasional dengan kultur komitmen organisasi mempunyai hubungan yang signifikan karena nilai t- statistik 26,864 diatas nilai t-tabel 1,96 dan mempunyai korelasi positif karena nilai original sampel diatas 0 yaitu 0,806 . Hubungan antara kepemimpinan transformasional dengan kinerja karyawan afektif mempunyai hubungan yang signifikan karena nilai t- statistik 50.939 diatas nilai t-tabel 1,96 dan mempunyai korelasi positif karena nilai original sampel diatas 0 yaitu 0,635. Hubungan antara kepemimpinan transformasional dengan kinerja karyawan afektif yang dimediasi oleh komitmen organisasi mempunyai hubungan yang tidak signifikan karena nilai t-statistik 4,709 dibawah nilai t- tabel 1,96 dan mempunyai korelasi positif karena nilai original sampel diatas 0 yaitu 0,336.

Hubungan antara kepemimpinan transformasional dengan kinerja karyawan afektif yang dimediasi oleh kultur kontrok mempunyai hubungan yang signifikan karena nilai tstatistik 3,978 diatas nilai t-tabel 1,96 dan mempunyai korelasi positif karena nilai original sampel diatas 0 yaitu 0,220. Dalam menilai struktural model PLS dapat dilihat berdasarkan nilai $R$-Square untuk setiap variabel latennya. Adapun nilai $R$-Square pada pengolahan data penelitian ini adalah sebagai berikut:

Tabel 2. R-Square

Variabel R Square




\begin{tabular}{ll}
\hline Kepemimpinan Transformasional & \\
\hline Kultur Kontrol & 0,624 \\
\hline Komitmen organisasi & 0,651 \\
\hline Kinerja Karyawan & 0,908 \\
\hline
\end{tabular}

Sumber: Output SmartPLS (2021)

Dari hasil tabel 2. diketahui bahwa $R$-Square dari dimensi kultur kontrol sebesar 0,624, dimensi komitmen organisasi sebesar 0,651, dimensi kepemimpinan transformasional 0,024 dan variabel kinerja karyawan sebesar 0,908 . Semakin tinggi $R$-square, maka semakin besar variabel independen tersebut dapat menjelaskan variabel dependen sehingga semakin baik persamaan struktural sedangkan sisanya dijelaskan oleh variabel-variabel lain diluar variabel yang diteliti dalam penelitian ini (Ghozali, 2012).

\section{Pembahasan}

\section{Pengaruh kepemimpinan Transformasional terhadap Kinerja Karyawan}

Pada penelitian ini, H1 menyatakan bahwa kepemimipinan transformasional berpengaruh positif signifikan terhadap kinerja karyawan. Berdasarkan hasil pengolahan data menggunakan software SmartPLS.3 diperoleh hasil perhitungan yang disajikan pada table 4.16. Diketahui bahwa nilai koefisien parameter dari variabel kepemimpinan trasnformasional terhadap kinerja karyawan adalah 0,870 dan nilai t-statistik sebesar 39,728 lebih besar dari nilai t-tabel yaitu 1,96. Pemimpin dengan gaya kepemimpinan transformasional akan mempengaruhi bawahannya untuk ikut serta dalam pencapaian tujuan organisasai karena pemimpin memiliki peran penting dalam mempengaruhi psikologis bawahnnya. Indikator yang di gunakan untuk mengukur kepemimpinan transformasional seperti stimulus intelektual yang diberikan pemimpin secara langsung akan dilihat oleh bawahnnya dan sikap tersebut akan memberikan pemahaman tersendiri untuk bawahnnya yang melihat dan akan memberikan dampak yang baik terhadap kinerja bawahnnya. Gaya kepemimpinan transformasional apabila pemimpin berhasil memengaruhi bawahan dengan visinya, menanamkan karismanya, memotivasi dan menjadi inspirator bagi karyawannya maka dapat dipastikan karyawan akan bekerja dengan baik, sungguh-sungguh dan loyal pada perusahaan sehingga kinerjanya meningkat (Robbins, 2010).

Dengan demikian Hipotesis 1 diterima. Sehingga dapat diambil kesimpulan bahwa kepemimpinan transformasional berpengaruh positif dan signifikan terhadap kinerja karyawan artinya semakin besar kepemimpinan transformasional maka implementasi akan semakin baik, sehingga menjadi efektif yang berdampak peningkatan kinerja karyawan. Pernyataan ini didukung dengan penelitian yang dilakukan oleh Modiani (2012) yang menemukan bahwa kepemimpinan transformasional berpengaruh positif terhadap kinerja karyawan.

\section{Pengaruh kepemimpinan Transformasional terhadap Kultur Kontrol}

Pada penelitian ini H2 menyatakan bahwa kepemimipinan transformasional berpengaruh positif signifikan terhadap kultur kontrol. Berdasarkan hasil pengolahan data menggunakan software SmartPLS diperoleh hasil perhitungan yang disajikan pada table 4.17. Diketahui bahwa nilai koeifisien parameter dari variable kepemimpinan trasnformasional 
terhadap kinerja karyawan adalah 0,789 dan nilai t-statistiknya sebesar 23,699 lebih besar dari nilai t-tabel yaitu 1,96. Kepemimpinan transformasional merupakan cara pemimpin untuk mentrasformasikan bawahannya karena dalam gaya kepemimpinan ini tidak diberlakukannya aturan atau pengawasan yang ketat dari pemimpin maka dari itu diperlukan norma yang mengikat supaya pemimpin tetap dapat memonitor bawahannya. Kultur kontrol merupakan bagian dari sistem pengendalian manajemen yang merupakan proses seorang manajer untuk memastikan sumber daya yang dimilikinya berjalan efektif dan efisien. Prilaku pemimpin dalam menjalankan kepemimpinan transformasional seperti memberikan perhatian yang individual dan motivasi akan membantu berjalannya pengendalian budaya karena akan mempengaruhi bawahannya yang melihatnya dan ikut menjalankan norma atau kode etik yang berlaku untuk dapat meningkatkan kinerjanya di organisasi. Dengan demikian Hipotesis 2 diterima. Sehingga dapat diambil kesimpulan bahwa kepemimpinan transformasional berpengaruh positif dan signifikan terhadap kultur kontrol artinya semakin besar kepemimpinan transformasional maka implementasi akan semakin baik, sehingga menjadi efektif yang berdampak peningkatan kultur kontrol.

\section{Pengaruh Kepemimpinan Transformasional terhadap Komitmen organisasi}

Pada penelitian ini H3 menyatakan bahwa kepemimipinan transformasional berpengaruh positif siginifikan terhadap kinerja karyawan. Berdasarkan hasil pengolahan data menggunakan software SmartPLS diperoleh hasil perhitungan yang disajikan pada table 4.18. Diketahui bahwa nilai koeifisien parameter dari variabel kepemimpinan trasnformasional terhadap kinerja karyawan adalah 0,806 dan nilai t-statistiknya sebesar 26,864 lebih besar dari nilai t-statistiknya yaitu 1,96. Komitmen organisasi melibatkan ikatan emosional yang bersifat jangka panjang, komitmen pada karyawan mucul dari prilaku pemimpin yang memberikan perhatian secara individual terhadap bawahnnya bawahnnya. Pemimpin yang akan membuat karyawan terikat secara emisonal. Hal ini membuat karyawan loyalitas tehadap organisasi yang nantinya akan meningkatkan kinerjanya dalam perusahaan. Dengan demikian Hipotesis 3 diterima. Sehingga dapat diambil kesimpulan bahwa kepemimpinan transformasional berpengaruh positif dan signifikan terhadap komitmen organisasi artinya semakin besar kepemimpinan transformasional maka implementasi akan semakin baik, sehingga menjadi efektif yang berdampak peningkatan komitmen organisasi. Kepemimpinan transformasional memberikan arahan kepada bahawannya dengan memberikan motivasi sehingga karyawan memiliki komitmen organisasi yang tinggi dalam berkerja hal ini di dukung oleh penelitian Dlamini et al (2017) menggunakan responden karyawan rumah sakit mengatakan bahwa ada korelasi positif dan signifikan antara kepemimpinan transformasional dan komitmen organisasi.

\section{Pengaruh Kultur Kontrol terhadap Kinerja Karyawan}

Pada penelitian ini H4 menyatakan bahwa kultur kontrol berpengaruh positif terhadap kinerja karyawan. Berdasarkan hasil pengolahan data menggunakan software SmartPLS diperoleh hasil perhitungan yangdisajikan pada table 4.19. Diketahui bahwa nilai koeifisien parameter dari variable kepemimpinan trasnformasional terhadap kinerja karyawan adalah 0,278 dan nilai t-statistiknya sebesar 4,861 lebih besar dari nilai t-statisticnya yaitu 1,96 . Dengan demikian Hipotesis 4 diterima. Sehingga dapat diambil kesimpulan bahwa kultur kontrol berpengaruh positif dan signifikan terhadap kinerja karyawan artinya semakin besar kultur kontrol maka Implementasi akan semakin baik, sehingga menjadi efektif yang berdampak peningkatan kinerja karyawan. Dengan demikian sebagai bagian dari MCS Culture Control 
berpengaruh terhadap kinerja organisasi dengan cara memberikan informasi yang berguna dalam pencapaian tujuan organisasi. Hal ini di dukung dengan adanya hasil penelitian oleh Mutaqqin (2017) yang menyatakan Cultur control berpengaruh positif terhadap kinerja karyawan.

\section{Komitmen organisasi terhadap Kinerja Karyawan}

Pada penelitian ini H5 menyatakan bahwa komitmen organisasi berpengaruh positif signifikan terhadap kinerja karyawan. Berdasarkan hasil pengolahan data menggunakan software SmartPLS diperoleh hasil perhitungan yang disajikan pada table 4.20. Diketahui bahwa nilai koeifisien parameter dari variable kepemimpinan trasnformasional terhadap kinerja karyawan adalah 0,454 dan nilai t-statistiknya sebesar 6,476 lebih besar dari nilai tstatisticnya yaitu 1,96 .

Seorang karyawan yang memiliki komitmen organisasi dalam dirinya akan menunjukkan rasa bangganya berada di organisasi sehingga muncul rasa memiliki karena menjadi bagian dari organisasi. Semakin tinggi komitmen organisasi dalam arti memiliki rasa senang sebagai bagian dari organisasi dan merasa bertanggung jawab untuk kemajuan organisasi tinggi maka karyawan akan menunjukkan hal positif bagi organisasi sehingga berdampak pada meningkatnya kinerja karyawan. Hal ini sesuai dengan penelitian Negin et al. (2013) membuktikan adanya pengaruh positif dan signifikan komitmen organisasi pada kinerja karyawan. Dengan demikian Hipotesis 5 diterima. Sehingga dapat diambil kesimpulan bahwa kultur kontrol berpengaruh positif dan signifikan terhadap kinerja karyawan artinya semakin besar kultur komitmen organisasi maka Implementasi akan semakin baik, sehingga menjadi efektif yang berdampak peningkatan kinerja karyawan.

\section{Kepemimpinan Transformasional terhadap Kinerja Karyawan melalui Kultur Kontrol sebagai mediator}

Pada penelitian ini H6 menyatakan bahwa hubungan kepemimpinan transformasional yang di mediasi kultur kontrol berpengaruh positif signifikan terhadap kinerja karyawan. Berdasarkan hasil pengolahan data menggunakan software SmartPLS diperoleh hasil perhitungan yang disajikan pada table 4.21. Diketahui bahwa nilai koeifisien parameter dari variable kepemimpinan trasnformasional terhadap kinerja karyawan adalah 0,220 dan nilai tstatistiknya sebesar 3,978 lebih besar dari nilai t-statisticnya yaitu 1,96. Kultur Kontrol sebagai variabel intervening dalam hipotesis ini bersifat parsial mediation karena jika di bandingkan dengan H1 yang mana hubungan Kepemimpinan Transformasional dan Kinerja Karyawan sudah positif dan signifikan maka ada atau tidaknya variabel Kultur Kontrol tidak mempengaruh hubungan antara Kepemimpinan Transformasional dan Kinerja Karyawan. Dengan demikian Hipotesis 6 diterima. Sehingga dapat diambil kesimpulan bahwa kepemimpinan transformasional yang di mediasi oleh kultur kontrol berpengaruh positif dan signifikan terhadap kinerja karyawan artinya semakin besar pengaruh kultur kontrol dalam mempengaruhi kepemimpinan trasnformasional maka implementasi akan semakin baik, sehingga menjadi efektif yang berdampak pada peningkatan kinerja karyawan.

\section{Kepemimpinan Transformasional terhadap Kinerja Karyawan melalui Komitmen organisasi sebagai mediator}

Pada penelitian ini $\mathrm{H} 7$ menyatakan bahwa hubungan kepemimpinan transformasional yang di mediasi komitmen organisasi berpengaruh positif signifikan terhadap kinerja karyawan. Berdasarkan hasil pengolahan data menggunakan software SmartPLS diperoleh 
hasil perhitunganyang disajikan pada tabel 4.22. Diketahui bahwa nilai koeifisien parameter dari variable kepemimpinan trasnformasional terhadap kinerja karyawan adalah 0,336 dan nilai t-statistiknya sebesar 4,709 lebih besar dari nilai t-statisticnya yaitu 1,96. Komitmen organisasi sebagai variabel intervening dalam hipotesis ini bersifat parsial mediation karena jika di bandingkan dengan $\mathrm{H} 1$ yang mana hubungan Kepemimpinan Transformasional dan Kinerja Karyawan sudah positif dan signifikan maka ada atau tidaknya variabel Komitmen organisasi tidak mempengaruhi hubungan antara Kepemimpinan Transformasional dan Kinerja Karyawan. Seorang karyawan yang memiliki komitmen organisasi dalam dirinya akan menunjukkan rasa senangnya berada di organisasi sehingga muncul rasa memiliki karena menjadi bagian dari organisasi. Semakin tinggi komitmen organisasi dalam arti memiliki rasa senang sebagai bagian dari organisasi dan merasa bertanggung jawab untuk kemajuan organisasi tinggi maka karyawan akan menunjukkan hal positif bagi organisasi sehingga berdampak pada meningkatnya kinerja karyawan. Dengan demikian Hipotesis 5 diterima. Sehingga dapat diambil kesimpulan bahwa komitmen organisasi memediasi hubungan antara kepemimpinan transformasional tehadap kinerja karyawan artinya semakin besar komitmen organisasi maka implementasi akan semakin baik, sehingga menjadi efektif yang berdampak peningkatan kinerja karyawan. Hal ini sesuai dengan penelitian Negin et al. (2013) membuktikan adanya pengaruhi positif dan signifikan komitmen organisasi pada kinerja karyawan. Hipotesis ini juga didukung oleh penelitian Almutairi (2016) yang menemukan bahwa terdapat pengaruh mediasi komitmen organisasi terhadap hubungan antara gaya kepemimpinan kepemimpinan transformasional dengan kinerja karyawan

\section{KESIMPULAN}

Berdasarkan hasil pengujian dan pembahasan sebagaimana telah disajikan dalam bab sebelumnya, maka dapat ditarik beberapa kesimpulan bahwa Kepemimpinan Transformasional berpengaruh positif dan signifikan terhadap Kinerja Karyawan. Dengan demikian semakin baik manajer mempunyai sifat Kepemimpinan Transformasional dalam suatu perusahaan maka semakin baik penerapan Kinerja Karyawan. Kepemimpinan Transformasional berpengaruh positif dan signifikan terhadap Kultur Kontrol. Dengan demikian semakin baik Kepemimpinan Transformasional manajer di perusahaan penerapan Kultur Kontrol juga akan semakin baik. Kulture Kontrol berpengaruh positif dan signifikan terhadap Kinerja Karyawan. Maksudnya ialah semakin kuat Kultur Kontrol dalam perusahaan maka semakin baik pula Kinerja Karyawan suatu perusahaan. Kepemimpinan Transformasional berpengaruh positif dan signifikan terhadap Komitmen organisasi. Dengan demikian semakin baik Kepemimpinan Transformasional manajer di perusahaan maka akan semakin mendorong juga Komitmen organisasi pada karyawan. Komitmen organisasi berpengaruh positif dan signifikan terhadap Kinerja Karyawan. Maksudnya ialah semakin berkembang Komitmen organisasi dalam perusahaan maka semakin meningkatkan Kinerja Karyawan suatu perusahaan.Kultur Kontrol memediasi hubungan antara Kepemimpinan Transformasional terhadap Kinerja Karyawan. Penelitian ini berhasil membuktikan pengaruh Kultur Kontrol sebagai variabel intervening bersifat parsial mediation karena jika di bandingkan dengan $\mathrm{H} 1$ yang menyatakan hubungan Kepemimpinan Transformasional dan Kinerja Karyawan sudah positif dan signifikan maka ada atau tidaknya variabel Kultur Kontrol tidak mempengaruhi hubungan antara Kepemimpinan Transformasional dan Kinerja Karyawan. Komitmen organisasi memediasi hubungan antara Kepemimpinan Transformasional terhadap Kinerja Karyawan. Penelitian ini berhasil membuktikan pengaruh Komitmen organisasi sebagai variabel intervening bersifat parsial mediation karena jika di bandingkan dengan H1 menyatakan hubungan Kepemimpinan 
Transformasional dan Kinerja Karyawan sudah positif dan signifikan maka ada atau tidaknya variabel Komitmen organisasi tidak mempengaruhi hubungan antara Kepemimpinan Transformasional dan Kinerja Karyawan.

\section{DAFTAR PUSTAKA}

Asbari, M. (2019). Pengaruh kepemimpinan transformasional dan iklim organisasi terhadap kinerja dosen. JOCE IP, 13(2), 172-186.

Asbari, M., Pramono, R., Kotamena, F., Juliana, Sihite, O. B., Alamsyah, V. U., Imelda, D., Setiawan, S. T., \& Purwanto, A. (2020). Bekerja Sambil Kuliah dalam Perspektif SelfManagement (Studi Etnografi pada Karyawan Etnis Jawa di Kota Seribu Industri Tangerang). Edumaspul - Jurnal Pendidikan, 4(1), 1-10.

Agistiawati, E., Asbari, M., Basuki, S., Yuwono, T., \& Chidir, G. (2020). Exploring the Impact of Knowledge Sharing and Organizational Culture on Teacher Innovation Capability. International Journal of Science and Management Studies (IJSMS), 3(3), 62-77.

Abouraia, M.K. \& Othman, S.M. (2017). Transformational Leadership, Job Satisfaction, Organizational Commitment, and Turnover Intentions: The Direct Effects among Bank Representatives. American Journal of Industrial and Business Management, 2017, 7, 404-423, DOI: 10.4236/ajibm.2017.74029.

Babin, B. J., \& Boles, J. S. (1998). Employee behavior in a service environment: A model and test of potential differences between men and women. Journal of Marketing, 62(2), 7791.

Bernardin, H., \& Russel, J. (1993). Human Resource Management: An Experimental Approach. Mc Graw Hill Companies.

Bernarto, I., Bachtiar, D., Sudibjo, N., Suryawan, I. N., Purwanto, A., \& Asbari, M. (2020). Effect of transformational leadership, perceived organizational support, job satisfaction toward life satisfaction: Evidences from indonesian teachers. International Journal of Advanced Science and Technology, 29(3), 5495-5503.

Clifton, G., et al. (2009). Gender and Job perfomance : Evidence from Wall Street.

Financial Analysts Journal . DOI 10.3386/w12897.

David, S., Armanu, \& Afnan, T. E. (2017). The Effects of Transformational Leadership and Personality on Employee Performance in Nissan Malang Mediated by Organizational Commitment. RJOAS, 3(19), 197-210.

Eliyana, A. (2019) 'Job satisfaction and organizational commitment effect in the transformational leadership towards employee performance', European Research on Management and Business Economics 25 (2019) 144-150. DOI:10.1016/j.iedeen.2019.05.001.

Eliyana, A., Ma'arif, S., \& Muzakki. (2019). Job satisfaction and organizational commitment effect in the transformational leadership towards employee performance. European Research on Management and Business Economics, 25(3), 144-150

Ghozali, I. (2014). Structural Equation Modeling, Metode Alternatif dengan Partial Least Square (PLS) (4th ed.). Badan Penerbit Universitas Diponegoro.

Gillet, N. And Vandenberghe, C. (2016) 'Transformational Leadership And Organizational Commitment: The Mediating Role Of Job Characteristics', Human Resource Development Quarterly. Doi: 10.1002/Hrdq.21192.

Haryati, E., Mariatin, E. And Supriyantini, S. (2014) 'Pengaruh Persepsi Kepemimpinan Transformasional Dan Budaya Organisasi Terhadap Organizational Citizenship Behavior', Analitika Jurnal Universita Sumatera Utara, 6(2), Pp. 105-113. Doi: Issn : 
2085-6601 Eissn : 2502-4590.

Ismail, T. (2016). Culture Control, Capability And Performance: Evidence From Creative Industries In Indonesia. Asian Review Of Accounting, 24(2), 171- 184.

Jumiran, Novitasari, D., Nugroho, Y. A., Sutardi, D., Sasono, I., \& Asbari, M. (2020). Pengaruh Dimensi Kepemimpinan Transformasional terhadap Kepuasan Kerja dan Komitmen Organisasional: Studi Kasus pada Dosen Perguruan Tinggi Swasta. EduPsyCouns: Journal of Education, Psychology and Counseling, 2(1), 600-621.

Kapiyangoda, K. And Gooneratne, T. (2018) 'Institutions, Agency, Culture And Control: A Case Study Of A Multinational Operating Company', Journal Of Accounting And Organizational Change, 14(4), Pp. 402-428. Doi: 10.1108/Jaoc-07-2017-0056.

Khalifa Elgelal, K. S., \& Noermijati, N. (2014). The Influences of Transformational Leaderships on Employees Performance (A Study of the Economics and Business Faculty Employee at University of Muhammadiyah Malang). Asia Pacific Management and Business Application, 3(1), 48-66.

Kranias, D. S. (2000). Cultural Control: The Case Of Japanese Multinational Companies And Their Subsidiaries In The Uk. Management Decision, 38(9), 638-649.

Luturlean, Bachruddin Saleh. (2018). Kepemimpinan Transformasional, Kepuasan Kerja, dan Komitmen organisasi pada Karyawan Perusahaan Bidang Konstruksi Milik Pemerintah di Medan. Jurnal Manajemen Indonesia. Vol, 18(3), pp. 209-221.

Matolcsy, B. And Zolomy, A. (2018) 'Practical Realization Rules And Cultur Control For Wideband Impedance Matching Using The Double-Terminated Filter Synthesis Method', In 2018 11th International Symposium On Communication Systems, Networks And Digital Signal Processing, Csndsp 2018. Doi: 10.1109/Csndsp.2018.8471872.

Muttaqin, G. F. (2017) 'Peningkatan Kinerja Karyawan Melalui Cultur Control Dan Gaya Kepemimpinan (Studi Pada Perusahaan Manufaktur Di Propinsi Kota dan Kabupaten Bekasi Tahun 2017)', Jurnal Riset Akuntansi Terpadu, 10(1), Pp. 101-121. Doi: 10.35448/Jrat.V10i1.4215.

Paccioni, A., Sicotte, C. And Champagne, F. (2008) 'Accreditation: A Cultural Control Strategy', International Journal Of Health Care Quality Assurance, 21(2), Pp. 146-158. Doi: 10.1108/09526860810859012.

Randy. (2013). Perananan Cultural Control Dalam Penerapan Code Of Conduct Karyawana Studi Kasus Pada Radio Suara Surabaya. Calyptra:Jurnal Ilmiah Mahasiswa Universitas Surabaya, 2(2), 1-12.

Rosiana, D. (No Date) 'Of Control Dan Disiplin Kerja Terhadap Kinerja Karyawan Studi Pada Perusahaan Daerah Pengelola Air Limbah ( Pd Pal ) Kota Banjarmasin’, (1), Pp. 91-102. Sugiyono, D. (2010). Metode Penelitian Kuantitatif Kualitatif Dan R\&D. Penerbit Alfabeta.

Uschi Backes-Gellner., et al. (2016). The Impact of Aging and Age Diversity on Company Performance. Institute for Strategy and Business Economics Plattenstrasse DOI:10.2139/ssrn.1346895.

Wahyuni, E. S. Rosmida, R. (2017) 'Analisis Pengaruh Budaya Organisasi, Locus Of Control Terhadap Kinerja Aparat Pemerintah Daerah Dan Kepuasan Kerja Sebagai Variabel Intervening (Studi Empiris Pada Pemerintah Kabupaten Bengkalis)', Inovbiz: Jurnal Inovasi Bisnis, 5(1), P. 12. Doi: 10.35314/Inovbiz.V5i1.165.

Yuwono, T., dkk. (2020). Analisis Pengaruh Efektivitas Kepemimpinan Transformasional dan Kesiapan Untuk Berubah Terhadap Kinerja Karyawan Wanita di Masa Pandemi Covid19. Jurnal Ilmiah Mahasiswa Ekonomi Manajemen. Vol. 5, No. 3, 2020 Agustus: 615632. 